\title{
Extracorporeal Photopheresis: A Case of Immunotherapy Ahead of Its Time
}

\author{
Pablo Augusto Vieyra-Garcia Peter Wolf \\ Department of Dermatology and Venerology, Medical University of Graz, Graz, Austria
}

\section{Keywords}

Extracorporeal photopheresis · Immunotherapy ·

Cutaneous T-cell lymphoma

\begin{abstract}
Extracorporeal photopheresis (ECP) is a cell-based immunotherapy that involves the reinfusion of autologous leukocytes after exposure to psoralen and UVA. The treatment has been used for over 30 years, at first on patients with cutaneous T-cell lymphoma (CTCL) and later for the management of patients with graft-versus-host disease (GvHD), sclerosing disorders, atopic dermatitis, and other diseases that may share the common driving factor of a pathogenic T-cell clone or clones in blood circulation. Patients with clinical improvement mount an antigen-specific immune response that may have tolerance traits in the case of GvHD or anticlonal cytotoxic characteristics in the case of CTCL. The exact mechanisms that dictate one response or the other are not fully understood, but the evidence accumulated so far indicates that multiple events occur simultaneously and consequentially contribute to the end result. These include contact of cells with the outside (plastics and tubing of the ECP apparatus), exposure to psoralen and UVA that activates platelets, monocytes, and other myeloid cells, the release of damageassociated molecular patterns, differentiation of monocytes
\end{abstract}

into dendritic cells, and generation and successive presentation of numerous antigens after the phagocytosis of apoptotic cells. Once reintroduced, the ECP product increases the frequency and activity of regulatory T cells (Tregs), shifts the systemic cytokine balance, and promotes extravasation of immune cells that together shape the effects of this treatment. In this review, we summarize the seminal work and most recent literature of the therapeutic mechanisms and reflect on future avenues of improvements and applications of ECP.

(c) 2020 S. Karger AG, Basel

\section{Background}

In the first few lines of the 1987 seminal paper on extracorporeal photopheresis (ECP), Edelson et al. [1] laid out the principle of their invention. After reflecting on the work of the group of Irun Cohen, who by those days had reported that the infusion of lethally damaged autoreactive $\mathrm{T}$-cell clones triggered a mechanism of resistance to subsequent elicitation of experimental autoimmune disease [2]. They realized that the work carried out by the group of Cohen demonstrated that the pathogenic activity of an aberrant population of $\mathrm{T}$ cells can be counteracted by an anti-clone-specific immune response and hy-
Pablo Augusto Vieyra-Garcia and Peter Wolf Department of Dermatology and Venerology, Medical University of Graz Auenbruggerplatz 8

AT-8036 Graz (Austria)

Pablo.vieyra-garcia@medunigraz.at and peter.wolf@medunigraz.at 
pothesized that a similar phenomenon may take place in humans [2]. Naturally, their impulse was to test their hypothesis in a clinical setup [1]. At that time, psoralen plus UVA (PUVA) was already widely used in the management of psoriasis and cutaneous T-cell lymphoma (CTCL) patients. It offered a way to induce extensive cellular damage with UVA irradiation and primarily target cells that have incorporated 8-methoxypsoralen (8-MOP) while sparing those not exposed to the drug. 8-MOP is a naturally occurring inert compound that, after irradiation with UVA, becomes a highly reactive molecule that binds covalently DNA, cell membranes, and proteins that together lead to cell death and other cytotoxic effects. Despite it not being formally proven, they suspected that PUVA contributed to the generation of numerous new antigens that primed a protective $\mathrm{T}$-cell response in a mechanism with the characteristics envisioned by the group of Cohen [2]. Not until nearly a decade later did the group of Edelson report that B-lymphoblastoid cells increase the expression of class I MHC up to 3-fold as a result of the degradation of cytoplasmic proteins upon exposure to photoactivated 8-MOP [3].

The first ECP trial [1] was a prospective study with Sézary syndrome patients, a variant of CTCL in which malignant cells not only infiltrate the skin but also circulate in the blood stream. An apheresis device with a circuitry of compartments for the exposure of leukocytes to UVA was used in 41 patients. Thirty-seven patients completed the study, 27 of whom presented clinical improvement, with an average reduction of $64 \%$ in skin score severity and a mean time to response of 22 weeks. Six patients failed to respond and 4 patients had no change and continued treatment. Twenty-eight patients participating in the study had a previous failed response to systemic chemotherapy, but 20 of them responded to ECP. At the end of the study, exfoliative erythroderma and focal hyperkeratosis improved significantly or were cleared [1]. In the following years, the evidence on the efficacy of ECP in Sézary syndrome was expanded.

At first a report on the case of a 43-year-old woman suffering graft-versus-host disease (GvHD) after allogenic bone marrow transplantation for chronic myeloid leukemia showed that, despite rapid deterioration of joints and muscles and liver damage, ECP was a viable option for successful treatment [4]. Soon after, a large prospective multicenter study with 95 chronic GvHD patients receiving standard steroid therapy alone $(n=47)$ or together with ECP $(n=48)$ was conducted. It revealed that, after 12 weeks of treatment, the skin score of patients on ECP had a median improvement of 14.5 versus $8.5 \%$ in the steroid only group and the ECP-treated patients experienced a substantial reduction in the requirement of corticosteroids [5]. Over the years, ECP has been introduced as new therapeutic option for a large number of other conditions, including sclerosing disorders [6-8], atopic dermatitis [9], and erythroderma of other origin [10, 11], and investigated as a preventive measure to reduce risk of heart [12], lung [13], and kidney [14] transplant rejection.

The therapeutic mechanisms triggered by ECP involve immunostimulatory, immunosuppressive, and immunotolerizing effects. These effects may at least to some extent depend on the type of disease (as is the case for conventional photo[chemo]therapy) $[15,16]$ and in one way or another contribute to the clinical improvement experienced by patients. We herein review the literature on the immunomodulatory effects of ECP and speculate about the future and innovations to come with this phototherapeutic modality.

\section{Apoptotic Fate of ECP-Exposed Cells}

Nearly $10 \%$ of total blood circulating mononuclear cells are drawn and exposed to 8-MOP and UVA during a regular ECP procedure [17]. Since then, in vitro studies have shown that treated cells follow different fates, e.g., immediate apoptosis of up to $15 \%$ with a flip-flop of phosphatidylserine to the outer membrane [18], cell cycle arrest observable from $24 \mathrm{~h}$ after exposure [19], and a second wave of apoptosis (driven by multiple factors) that culminates with absolute killing of exposed cells on in vitro cultures between 48 and $72 \mathrm{~h}$ after ECP [20-22] (Fig. 1). The susceptibility to ECP-induced apoptosis varies from cell type to cell type. In a recent study with healthy volunteers, B cells and NK cells were severely affected 24 $\mathrm{h}$ after treatment, with over $70 \%$ of annexin V+ cells increasing up to $90 \%$ after $48 \mathrm{~h}$ [21]. T lymphocytes are also highly susceptible to 8-MOP/UVA exposure likely due to a rapid downregulation of STAT5, a downstream kinase of IL-2 that coregulates the balance of Bcl-2 family proteins and activation of caspases $[23,24]$. In contrast, regulatory $\mathrm{T}$ cells (Tregs) are more resilient to ECP, with apoptosis levels below $30 \%$ at $24 \mathrm{~h}$ and levels of $30-65 \%$ $48 \mathrm{~h}$ after treatment [21]. Monocytes reached levels of apoptosis above $90 \% 72 \mathrm{~h}$ after treatment [21]. However, an independent study showed that 8-MOP/UVA-exposed monocytes retain their capacity to secrete proinflammatory cytokines in response to LPS even after they initiate apoptosis, and those who survive are able to differentiate into dendritic cells (DC) when cultured with IL-4 and GM-CSF [25].

\section{Mitochondrial Alterations and Bcl-2 Family Proteins}

Used alone, 8-MOP increases the ratio of $\mathrm{Bax} / \mathrm{Bcl}-2$ in hepatocellular carcinoma (HepG2) cells by decreasing the expression of DEC1 and effectively affecting cell via- 


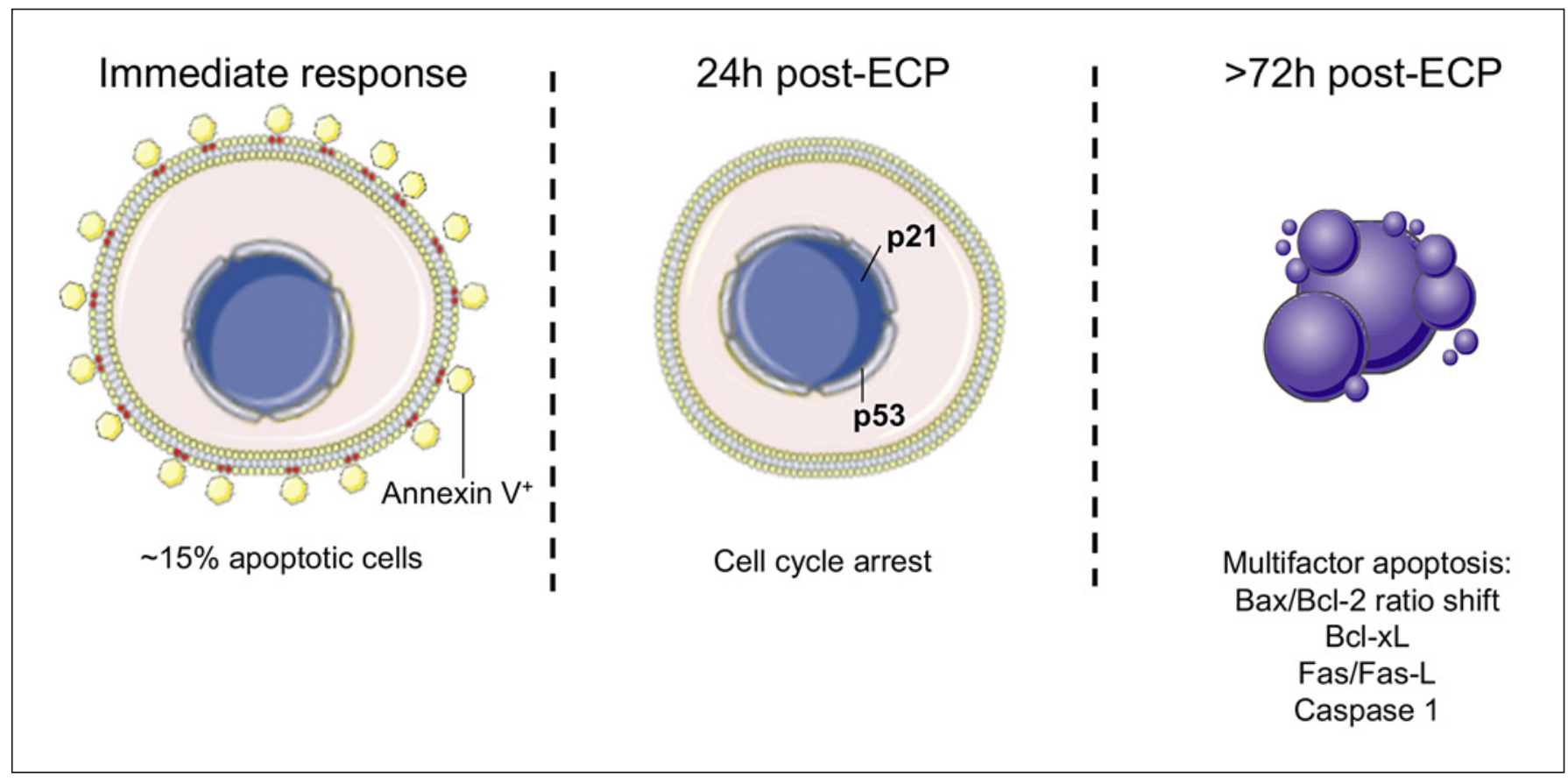

Fig. 1. Cell cycle arrest and commitment to apoptosis of ECP-exposed cells. Upon exposure to ECP cells that suffer extensive DNA damage, fail to repair it or bear severe mitochondrial alterations initiate a gradual process of apoptosis. Severely affected cells have an immediate flip-flow of phosphatidylserine, others halt cell cycle via activation of p21 and p53, and apoptotic bodies appear as early as $72 \mathrm{~h}$ after treatment as a result of activation of both intrinsic and extrinsic apoptosis pathways.

bility [26]. The Bcl-2 family proteins are central regulators of mitochondrial dependent apoptosis. The increase in Bax induces apoptosis commitment by the formation of oligomers that compromise mitochondrial membrane integrity, the translocation of apoptotic proteins such as AIF, cytochrome $\mathrm{C}$, and the activation of caspases that lead to activation of the intrinsic pathway of apoptosis [27]. Exposure to 8-MOP/UVA also disrupts the opening regulation of permeability transition pores, causing a disturbance of membrane potential, liberation of ROS, and generation of psoralen photoproducts [28]. Once these photoproducts (a group of photodegraded intermediaries of psoralen) are released, they exert a potent cytotoxic activity given their high reactivity with proteins and unsaturated lipids [29].

Histological analysis of psoriatic lesions treated with PUVA and normal skin of patients have shown a prominent reduction of $\mathrm{Bcl}-2$ expression in lymphocytes and keratinocytes together with a high score of apoptosis [30]. A similar reduction of Bcl-2 expression has been found comparing lymphocytes prior ECP treatment and immediately after irradiation (before reinfusion into the patient), altering the $\mathrm{Bcl}-2 / \mathrm{Bax}$ ratio [23]. Evidence suggests that the induction of apoptosis observed $24 \mathrm{~h}$ after ECP may be mediated by independent but at the same time synergizing mechanisms. In fact, 2 studies carried out in patients with systemic scleroderma showed that blood drawn 1 day after ECP had a high frequency of CD4 T cells with a high expression of CD95, a major regulator of extrinsic apoptosis [31,32]. In vitro studies suggest that CD95 can cooperate with Bcl-xL and Bcl-2 to mobilize $\mathrm{Ca} 2+$ inside the mitochondria [33]. In mouse epidermal cells, exposure to 8-MOP/UVA results in p53 stabilization and nuclear translocation that triggers CD95 expression as early as $48 \mathrm{~h}$ after irradiation $[34,35]$.

\section{P53 and Alteration of Cell Signaling}

PUVA-induced p53 activation is preceded by increased expression of $\mathrm{p} 21$, a protein associated with cell cycle arrest in the G1 phase and subsequent apoptosis [36]. Additionally, p21 is a potent suppressor of the PI3K pathway during cell cycle arrest [37]. In fact, hitting PI3K may be a prominent factor in the therapeutic effect of $\mathrm{ECP}$ as the PI3K pathway is often involved in oncogenesis of CTCL patients and the severity of GvHD in animal models $[38,39]$. 8-MOP/UVA exposure decreases the decoding of signal transduction by inducing changes in the cell membrane as a consequence of 8-MOP intercalation and covalent binding to phospholipids [40]. This inhibits the recruitment of effector kinases including Akt and Btk, affecting the PI3K pathway and rendering T cells unresponsive to IL-2 and TCR stimulus [41]. 


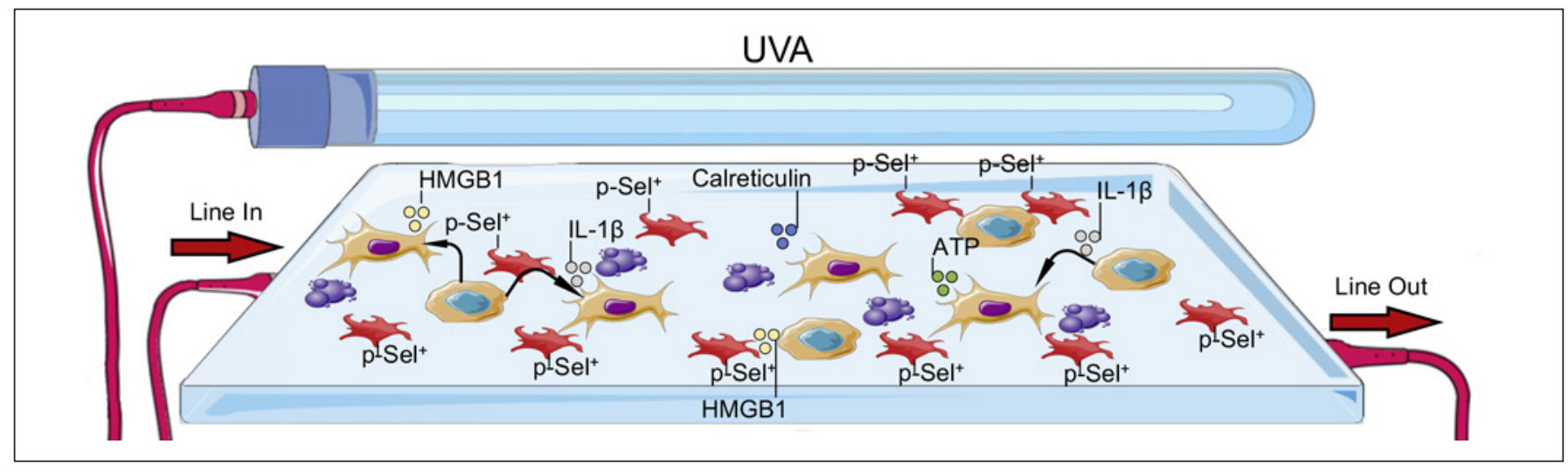

Fig. 2. Activated platelets contribute to APC activation. In parallel to the induction of apoptosis, the exposure to 8-MOP/UVA and the contact with tubing and plastics of the ECP apparatus induce changes in multiple blood components. Platelets are activated, adhere to the walls of the irradiation chamber, and express p-selecting. Extracellular ATP, IL-1 $\beta$, HGMB1, and other DAMP are secreted and collectively promote monocyte differentiation into DC. A prolonged incubation in the irradiation chamber seems to promote phagocytosis of apoptotic cells and presentation of new antigens in a process referred as transimmunization.

\section{Immunomodulatory Effects of ECP}

Once reinfused, the ECP product represents only a minor fraction of the cells in peripheral circulation. Multiple interactions between apoptotic bodies and exposed and nonexposed cells initiate a cascade of immunological changes that cement the core elements of the ECP therapeutic mechanism. As patients benefit from a response with anticlonal and/or immunotolerance characteristics and they do not enter into a generalized immunosuppression state (opportunistic infections are rarely seen in ECP-treated patients and they have a normal response to vaccination) $[42,43]$, it is reasonable to infer that ECP provides a pool of antigens and immunomodulatory mediators that resettle the immune system. This, however, challenges one of the long-standing assumptions that apoptosis is a silent modality of cell death that prevents the elicitation of autoimmunity [44]. The evidence suggests that this is not always the case. Indeed, it has been shown that keratinocytes in apoptosis often display antigen determinants that are likely generated after caspases carry out degradation of endogenous proteins [45]. The numerous photoadducts formed between UVA-activated psoralen and amino acids may also modify the enzymatic processing of proteins and generate neo-antigens that increase the immunogenicity of irradiated cells [46]. Consequently, with this hypothesis, 8-MOP/UVA exposure leads to a substantial increase of MHC class I expression and a higher density display of peptides in transformed lymphocytes as early as $20 \mathrm{~h}$ after treatment [3]. In comparison with 8-MOP/UVA, no other agents including UVB, mitomycin $\mathrm{C}$, and $\gamma$-irradiation had such potency of cytoplasmic protein degradation and presentation of antigenic peptides [3, 47].

\section{Platelet Activation and Differentiation of Monocytes into $D C$}

As outlined, not all cells are equally susceptible to ECP. Monocytes are highly resistant to 8-MOP/UVA exposure and increase phagocytosis of apoptotic cells in response to irradiation [48]. Parallel to that, platelets are activated, their adherence is increased, and they engage with monocytes promoting their differentiation into DC in a process mediated by p-selectin $[49,50]$ (Fig. 2). An ingenious modeling work of ECP in mice confirmed that monocyte-to-DC differentiation takes place soon after 8-MOP/UVA exposure and demonstrated that antigens from melanoma can be processed and presented by freshly differentiated DC [51]. The tumor antigens loaded in these cells makes them effective vaccine agents to prevent tumor development as long as their viability is not compromised by ECP [51]. Interestingly, it seems that the characteristics of these ECP-induced DC make them superior initiators of T-cell responses in contrast to DC generated by other methods that employ cytokine cocktails ex vivo at nonphysiological levels [52]. Such methods take several days to select positively cell populations that presumably once reintroduced in the patient do not find adequate levels of cytokines for their survival and have limited clinical performance when used in cancer immunotherapy $[53,54]$. In contrast to that, ECP may be one of the most practical approaches to load tumor antigens into potent antigen-presenting cells (APC) as evidenced in a study on CTCL patients in which the addition of overnight incubation of ECP-treated cells prior reinfusion promoted the processing and presentation of antigens from tumor cells by freshly differentiated monocytes in a process described as "transimmunization" [55]. A transcriptomic analysis of monocytes $18 \mathrm{~h}$ after exposure to ECP showed a 


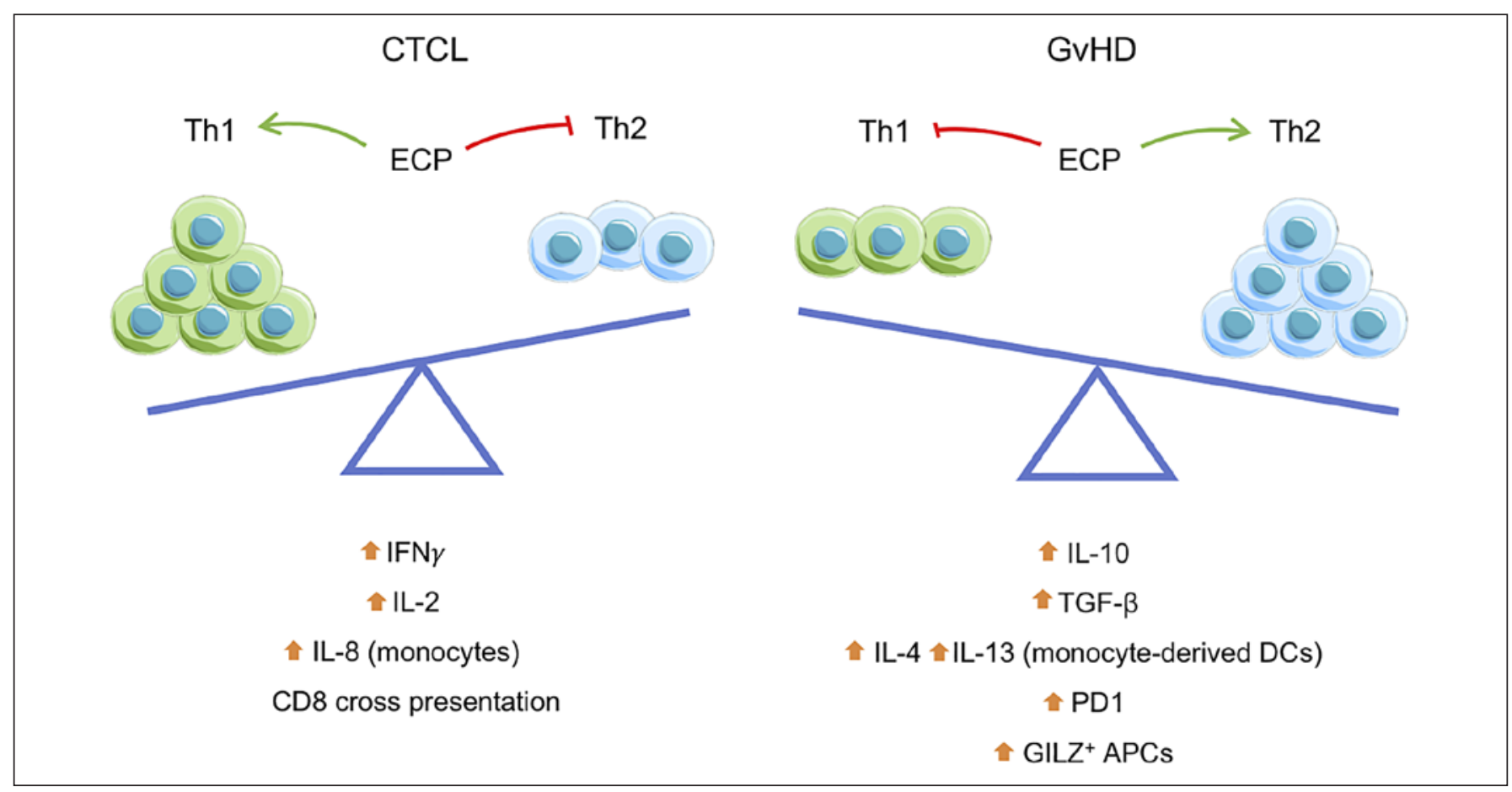

Fig. 3. Dual effect of ECP on antigen-specific immune and clinical responses. Upon reintroduction of treated cells, patients experience a shift in Th1 and Th2 balance closely associated with the type of disease. Whereas CTCL frequently respond to ECP with a shift toward a Th1 type response and cytotoxic CD $8 \mathrm{~T}$ cells are primed by crosspresentation, GvHD patients often transit to a Th2 type response with immunomodulatory cytokines such as IL-10 and TGF- $\beta$ closely related to the upregulation of PD1 and expression of GILZ in APC.

shift of over 1,100 genes including 20 genes associated with DC function and 60 genes participating in transmembrane signaling [56]. ECP-generated DC exceled at stimulating cytotoxic $\mathrm{CD} 8 \mathrm{~T}$ cells with melanoma tumor antigens via MHC class I cross-presentation in a mouse model [57]. A recent report suggests that the potency of ECP-generated DC relays on the emission of damage-associated molecular patterns (DAMP) that augment phagocytic, chemotactic, and activation potential [58]. In particular, calreticulin exposure stimulates phagocytic activity. HMGB1 is a nuclear protein with adjuvant properties mediated by TLR4 binding, and extracellular ATP secreted during autophagy promotes chemotaxis via $\mathrm{P} 2 \mathrm{Y} 2$ receptor $[58,59]$. An in vitro study modeling GvHD indicated that pathogenic T cells express calreticulin and release HMGB1 after 8-MOP/UVA exposure, substantially increasing their phagocytosis by DC [60]. IL-1 $\beta$ is a potent inflammatory cytokine that synergizes with IL-2 to promote antitumoral cytotoxic activity in CD8+ T cells, inhibits the formation of Tregs, and plays a pathogenic role through the interactions of DC and T cells in inflammatory diseases such as rheumatoid arthritis [6163]. A recent report with data from a mouse model and ECP-treated patients indicates that 8-MOP/UVA exposure has prominent immunostimulatory consequences closely associated with the release of IL-1 $\beta$ [64]. Monocytes and myeloid DC produced IL-1 $\beta$ after ECP in a mechanism pre- dominantly independent of caspase- 1 activation and in vitro culture of these cells showed a robust survival of professional APC for up to 7 days [64] (Fig. 2). Altogether these findings collectively indicate that ECP can in fact provide the third signal for T-cell priming through the production of soluble immunostimulatory factors.

A study on leukemic (L-CTCL) and GvHD patients demonstrated how the effect of ECP is translated into frequency changes of DC subpopulations in the periphery by monitoring the rate of CD123+ plasmacytoid DC (pDC) and $\mathrm{CD} 11 \mathrm{c}+$ myeloid $\mathrm{DC}(\mathrm{mDC})$. It showed that both $\mathrm{pDC}$ and $\mathrm{mDC}$ were normalized and further increased in GvHD patients, while in L-CTCL patients pDC remained unaltered and $\mathrm{mDC}$ were substantially augmented over a 3- to 6-month period of ECP treatment [65]. In addition to that, the majority of responding L-CTCL patients increased the expression of HLA-DR in both populations of $\mathrm{DC}$, reinforcing the association of DC maturation to the therapeutic mechanism of ECP [65].

\section{Modulation of Antigen-Specific T-Cell Responses}

Reports on the effects of ECP in the production of inflammatory mediators are controversial. Whereas postECP monocytes in culture upregulate TNF- $\alpha$ and IL-6 
production, serum levels of TNF- $\alpha$ tend to decrease and normalize in responding GvHD patients [66, 67]. A cytokine profiling study of CTCL patients revealed that, after 8-MOP/UVA exposure, peripheral blood mononuclear cells exhibit enhancement of IFN- $\gamma$ and IL-2 production together with a decline of IL-4 and IL-10 [68]. This occurred not at the expense of Th2 cells converting into Th1; instead, the overall number of Th1 cells increased together with their cell-to-cell interactions, initiating feedback mechanisms that stimulated the production of IL-8 in monocytes [68]. In fact, it is generally understood that CTCL patients experience a transition after ECP to Th1 restoration and a lower production of pathogenic Th2 cytokines $[69,70]$.

In contrast to the elusive switch from a predominant Th2 to a Th1 cytokine microenvironment harnessed by ECP, studies addressing the secretory capacity of peripheral blood mononuclear cells of GvHD patients and in vitro models of allogenic reactions revealed that ECP exposure can increase the production of Th2 cytokines including IL-10 and TGF- $\beta$ [71-73] (Fig. 3). Indeed, GvHD patients benefit from an induction of Th2 polarization after multiple rounds of ECP $[71,74]$. Monocyte-derived DC exposed to 8-MOP/UVA skew naive T cells towards a Th2 like response with increased production of IL-4, IL10 , and IL-13, while the production of Th1 cytokines is substantially suppressed $[75,76]$. The internalization of apoptotic cells may decrease the inflammatory reaction of phagocytes, inhibit the transcription of IL-12 in nonirradiated cells, and induce antigen-specific immunotolerance [77-79]. In vitro priming of T cells with ECP-exposed monocytes increases IFN- $\gamma$ and IL-17 production but reduces the proliferation capacity of $\mathrm{T}$ cells in response to TCR stimulation in a cell contact mechanism regulated by transient PD-1 interactions [80]. Expression of the glucocorticoid-induced leucine zipper (GILZ) (an inhibitor of multiple pathways including NF- $\mathrm{kB}$ ) is a distinctive characteristic of tolerogenic DC and it is increased by 8 -MOP/UVA exposure $[81,82]$. As a consequence, these cells downregulate CD80 and CD86, become unresponsive to TLR-induced maturation, and have a higher production of IL-10 and lower IL-12p70 levels [82]. The tolerogenic profile of DC is gradually induced by ECP, and in fact the same study suggests that minimal exposure to 8-MOP/UVA enhances immunogenic properties of myeloid cells in an invitro assay [82].

\section{Activation of Tregs}

Mouse models of contact hypersensitivity have shown that the infusion of 8-MOP/UVA-irradiated cells from sensitized mice inhibit the immune response once injected into naive animals [83]. Depletion of the CD11c+ and not the T-cell fraction prior to infusion reverses the inhibitory effect of 8-MOP/UVA mediated by the elicitation of antigen-specific CD4+ CD25+ T cells and the production of IL-10 in the sensitization and effector phase $[83,84]$. The magnitude of the immunomodulatory effect of ECP during the effector phase can be observed in a mouse model of GvHD where treated cells from the donor were able to revert the already established disease and depletion of donor Tregs proved that these cells played a major role in decreasing disease severity [85].

A follow-up study in GvHD patients under ECP showed that, after 3 months and up to 1 year of treatment, $\mathrm{CD} 4+, \mathrm{CD} 8+$, and Tregs in circulating blood increased in frequency but the $\mathrm{CD} 4+/$ Tregs ratio remained unaltered $[86,87]$. Tregs in the circulation of patients under ECP expressed high levels of CD62L, CD45RO, and Foxp3 and had a potent suppressive function on allogenic effector $\mathrm{T}$ cells, reducing the IFN- $\gamma$ secretion mediated by cell contact interactions [88]. Although no gains in the production of IL-10 and TGF- $\beta$ were found in ECP-induced Tregs [88], a functional study in GvHD patients with cells obtained $48 \mathrm{~h}$ after treatment showed that CD39 (an ectonuclotidase responsible of adenosine production) is upregulated in Tregs and participates in the conversion of ATP into adenosine in the extracellular medium [89]. Adenosine production is a known immunosuppressive mechanism that involves the coordinated expression of CD39 and CD73 in Tregs to deliver a signal to effector cells through stimulation of the adenosine $\mathrm{A} 2 \mathrm{~A}$ receptor [90]. Although these findings suggest a role of Tregs in the therapeutic effect of ECP, a recent prospective study in 32 chronic GvHD patients showed a significant increase in Tregs during the first 6 months of treatment but no statistical association between Tregs and skin or steroid response; there was also a large variability in the absolute count and frequency of these cells [91]. In the last few years, experimental models of ECP have shown that classical Tregs are not the only subpopulation of cells with IL-10-mediated immunomodulatory properties. A mouse model of skin allograft showed that the infusion of splenocytes exposed to 8-MOP/UVA increased the number of IL-10+ regulatory B cells in circulation and promoted survival of the graft [92]. In contrast to that, a study in chronic GvHD patients under ECP revealed that serum levels of B-cell activating factor may be a biomarker of negative treatment outcomes as high levels of B-cell activating factor (BAFF) were associated with a worse median skin score after 6 months of treatment, whereas patients with low levels $(<4 \mathrm{ng} / \mathrm{ml})$ exhibited substantial skin improvement and had a high rate $(>50 \%)$ of complete resolution [93]. Moreover, a recent report suggests that ECP also induces the formation of a CD8 T-cell subset with a suppressive capacity on CD8 effector cells via an indirect mechanism that involves the inhibition of 
priming functions and migration out of the skin of APC [94]. Interestingly, these CD8 cells with a suppressive function did not show characteristics of regulatory CD8 cells including IL-10-mediated suppression or expression of Foxp3.

\section{Concluding Remarks}

ECP is an immunotherapy that arose way ahead of its time, proving that observations in basic research can quickly translate into principles for clinical application. Today, with better insight into the critical phenomena occurring during 8-MOP/UVA exposure, contact with non-self-materials of the ECP devices, and reinfusion into the blood stream, improvements in treatment protocols and further applications of ECP as a DC modifier therapy are imminent. It is clear that the immunomodulatory effect of ECP is primarily antigen specific and the dual pro/anti-inflammatory effect relies on interactions of cells that have initiated apoptosis with 2 kinds of APC, i.e., phagocytosis by nonexposed APC that result in immunoregulation and phagocytosis by ECP-activated myeloid cells in the presence of proinflammatory mediators such as IL-1 $\beta$ that result in immunostimulation.

As the immunomodulatory effects of ECP have direct and indirect reach across multiple cells in circulation, understanding the factors that determine the type of response and their role in therapeutic mechanisms is a challenging task. However, disruptive technologies such as
scRNA-seq, ChIP-seq, and CyTOF have become available to address complex immune networks. Indeed, we live in times when we can look at transcriptional programs and cell interactions with incredible detail. With those tools at hand, further work is yet to be carried out to understand clearly how to procure a specific effect for the desired purpose by engineering systems that optimize platelet activation and DC differentiation as well as offline devices that facilitate customizable times of incubation prior to reinfusion of cells.

\section{Acknowledgment}

The authors are very grateful to H.N. Ananthaswamy, Houston, TX, USA) for critical reading of this paper.

\section{Funding Sources}

This work was supported by FWF Austrian Science Fund No. W1241 to P.W. P.A.V.-G. had funding support from the Fondation René Touraine-Celgene and the European Academy of Dermatology and Venereology.

\section{Author Contributions}

P.A.V.-G. and P.W. conceived the ideas. P.A.V.-G. drafted this paper and created the figures, modifying graphic material from Servier licensed under a Creative Commons Attribution 3.0 Unported License. Both authors revised and approved the final version of this paper for publication.

\section{References}

1 Edelson R, Berger C, Gasparro F, Jegasothy B, Heald P, Wintroub B, et al. Treatment of cutaneous T-cell lymphoma by extracorporeal photochemotherapy. Preliminary results. N Engl J Med. 1987 Feb;316(6):297-303.

2 Holoshitz J, Naparstek Y, Ben-Nun A, Cohen IR. Lines of T lymphocytes induce or vaccinate against autoimmune arthritis. Science. 1983 Jan;219(4580):56-8.

3 Hanlon DJ, Berger CL, Edelson RL. Photoactivated 8-methoxypsoralen treatment causes a peptide-dependent increase in antigen display by transformed lymphocytes. Int J Cancer. 1998 Sep;78(1):70-5.

4 Owsianowski M, Gollnick H, Siegert W, Schwerdtfeger R, Orfanos CE. Successful treatment of chronic graft-versus-host disease with extracorporeal photopheresis. Bone Marrow Transplant. 1994 Nov; 14(5): 845-8.

5 Flowers ME, Apperley JF, van Besien K, Elmaagacli A, Grigg A, Reddy V, et al. A multicenter prospective phase 2 randomized study of extracorporeal photopheresis for treatment of chronic graft-versus-host disease. Blood. 2008 Oct;112(7):2667-74.

6 Knobler R, Moinzadeh P, Hunzelmann N, Kreuter A, Cozzio A, Mouthon L, et al. Euro- pean Dermatology Forum S1-guideline on the diagnosis and treatment of sclerosing diseases of the skin, Part 1: localized scleroderma, systemic sclerosis and overlap syndromes. J Eur Acad Dermatol Venereol. 2017 Sep;31(9):1401-24.

7 Knobler R, Moinzadeh P, Hunzelmann N, Kreuter A, Cozzio A, Mouthon L, et al. European dermatology forum S1-guideline on the diagnosis and treatment of sclerosing diseases of the skin, Part 2: Scleromyxedema, scleredema and nephrogenic systemic fibrosis. J Eur Acad Dermatol Venereol. 2017 Oct;31(10): 1581-94.

8 Muellegger RR, Hofer A, Salmhofer W, Soyer HP, Kerl H, Wolf P. Extended extracorporeal photochemotherapy with extracorporeal administration of 8-methoxypsoralen in systemic sclerosis. An Austrian single-center study. Photodermatol Photoimmunol Photomed. 2000 Oct;16(5):216-23.

9 Knobler R, Berlin G, Calzavara-Pinton P, Greinix H, Jaksch P, Laroche L, et al. Guidelines on the use of extracorporeal photopheresis. J Eur Acad Dermatol Venereol. 2014 Jan;28 Suppl 1:1-37.

10 Hofer A, Müllegger R, Kerl H, Wolf P. Extracorporeal photochemotherapy for the treat- ment of erythrodermic pityriasis rubra pilaris. Arch Dermatol. 1999 Apr;135(4):475-6.

11 Wolf P, Müllegger R, Cerroni L, Aigner R, Fueger G, Höfler G, et al. Photoaccentuated erythroderma associated with CD4+ T lymphocytopenia: successful treatment with 5-methoxypsoralen and UVA, interferon alfa- $2 \mathrm{~b}$, and extracorporeal photopheresis. J Am Acad Dermatol. 1996 Aug;35(2 Pt 2): 291-4.

12 Patel J, Klapper E, Shafi H, Kobashigawa JA. Extracorporeal photopheresis in heart transplant rejection. Transfus Apheresis Sci. 2015 Apr;52(2):167-70.

13 Hachem R, Corris P. Extracorporeal Photopheresis for Bronchiolitis Obliterans Syndrome After Lung Transplantation. Transplantation. 2018 Jul;102(7):1059-65.

14 Horina JH, Müllegger RR, Horn S, Holzer H, Halwachs G, Kerl H, et al. Photopheresis for renal allograft rejection. Lancet. 1995 Jul; 346(8966):61.

15 Vieyra-Garcia PA, Wolf P. From Early Immunomodulatory Triggers to Immunosuppressive Outcome: Therapeutic Implications of the Complex Interplay Between the Wavebands of Sunlight and the Skin. Front Med (Lausanne). 2018 Sep;5:232. 
16 Yu Z, Wolf P. How It Works: The Immunology Underlying Phototherapy. Dermatol Clin. 2020 Jan;38(1):37-53.

17 Knobler R, Barr ML, Couriel DR, Ferrara JL, French LE, Jaksch P, et al. Extracorporeal photopheresis: past, present, and future. J Am Acad Dermatol. 2009 Oct;61(4):652-65.

18 Gerber A, Bohne M, Rasch J, Struy H, Ansorge $\mathrm{S}$, Gollnick $\mathrm{H}$. Investigation of annexin $\mathrm{V}$ binding to lymphocytes after extracorporeal photoimmunotherapy as an early marker of apoptosis. Dermatology. 2000;201(2):111-

19 Bartosová J, Kuzelová K, Pluskalová M, Marinov I, Halada P, Gasová Z. UVA-activated 8-methoxypsoralen (PUVA) causes G2/M cell cycle arrest in Karpas 299 T-lymphoma cells. J Photochem Photobiol B. 2006 Oct; 85(1):39-48.

20 Bladon J, Taylor PC. Extracorporeal photopheresis in cutaneous T-cell lymphoma and graft-versus-host disease induces both immediate and progressive apoptotic processes. $\mathrm{Br}$ J Dermatol. 2002 Jan;146(1):59-68.

21 Budde H, Berntsch U, Riggert J, Legler TJ. In vitro effects of different 8-methoxypsoralen treatment protocols for extracorporeal photopheresis on mononuclear cells. Cent Eur J Immunol. 2017;42(1):1-9.

22 Johnson R, Staiano-Coico L, Austin L, Cardinale I, Nabeya-Tsukifuji R, Krueger JG. PUVA treatment selectively induces a cell cycle block and subsequent apoptosis in human T-lymphocytes. Photochem Photobiol. 1996 May;63(5):566-71.

23 Bladon J, Taylor PC. Lymphocytes treated by extracorporeal photopheresis demonstrate a drop in the $\mathrm{Bcl}-2 / \mathrm{Bax}$ ratio: a possible mechanism involved in extracorporeal-photopheresis-induced apoptosis. Dermatology. 2002; 204(2):104-7.

24 Debierre-Grockiego F. Anti-apoptotic role of STAT5 in haematopoietic cells and in the pathogenesis of malignancies. Apoptosis. 2004 Nov;9(6):717-28.

25 Hannani D, Merlin E, Gabert F, Laurin D, Deméocq F, Chaperot L, et al. Photochemotherapy induces a faster apoptosis of alloreactive activated $\mathrm{T}$ cells than of nonalloreactive resting $\mathrm{T}$ cells in graft versus host disease. Transplantation. 2010 Dec;90(11):1232-8.

26 Peng Y, Liu W, Xiong J, Gui HY, Feng XM, Chen $\mathrm{RN}$, et al. Down regulation of differentiated embryonic chondrocytes 1 (DEC1) is involved in 8-methoxypsoralen-induced apoptosis in HepG2 cells. Toxicology. 2012 Nov; 301(1-3):58-65.

27 Dewson G, Kluck RM. Mechanisms by which Bak and Bax permeabilise mitochondria during apoptosis. J Cell Sci. 2009 Aug;122(Pt 16): 2801-8.

28 Canton M, Caffieri S, Dall'Acqua F, Di Lisa F. PUVA-induced apoptosis involves mitochondrial dysfunction caused by the opening of the permeability transition pore. FEBS Lett. 2002 Jul;522(1-3):168-72.

29 Caffieri S, Di Lisa F, Bolesani F, Facco M, Semenzato G, Dall'Acqua F, et al. The mitochondrial effects of novel apoptogenic molecules generated by psoralen photolysis as a crucial mechanism in PUVA therapy. Blood. 2007 Jun;109(11):4988-94.
30 El-Domyati M, Moftah NH, Nasif GA, AbdelWahab HM, Barakat MT, Abdel-Aziz RT. Evaluation of apoptosis regulatory proteins in response to PUVA therapy for psoriasis. Photodermatol Photoimmunol Photomed. 2013 Feb;29(1):18-26.

31 Aringer M, Graninger WB, Smolen JS, Kiener HP, Steiner CW, Trautinger F, et al. Photopheresis treatment enhances CD95 (fas) expression in circulating lymphocytes of patients with systemic sclerosis and induces apoptosis. Br J Rheumatol. 1997 Dec;36(12): 1276-82.

32 Papp G, Barath S, Szegedi A, Szodoray P, Zeher M. The effects of extracorporeal photochemotherapy on $\mathrm{T}$ cell activation and regulatory mechanisms in patients with systemic sclerosis. Clin Rheumatol. 2012 Sep;31(9): 1293-9.

33 Fouqué A, Lepvrier E, Debure L, Gouriou Y, Malleter M, Delcroix V, et al. The apoptotic members CD95, BclxL, and Bcl-2 cooperate to promote cell migration by inducing $\mathrm{Ca}(2+)$ flux from the endoplasmic reticulum to mitochondria. Cell Death Differ. 2016 Oct;23(10): 1702-16.

34 Santamaria AB, Davis DW, Nghiem DX, McConkey DJ, Ullrich SE, Kapoor M, et al. p53 and Fas ligand are required for psoralen and UVA-induced apoptosis in mouse epidermal cells. Cell Death Differ. 2002 May;9(5):54960.

35 Müller M, Wilder S, Bannasch D, Israeli D, Lehlbach K, Li-Weber M, et al. p53 activates the CD95 (APO-1/Fas) gene in response to DNA damage by anticancer drugs. J Exp Med. 1998 Dec;188(11):2033-45.

36 Viola G, Fortunato E, Cecconet L, Del Giudice L, Dall'Acqua F, Basso G. Central role of mitochondria and p53 in PUVA-induced apoptosis in human keratinocytes cell line NCTC-2544. Toxicol Appl Pharmacol. 2008 Feb;227(1):84-96.

37 Izutani Y, Yogosawa S, Sowa Y, Sakai T. Brassinin induces G1 phase arrest through increase of p21 and p27 by inhibition of the phosphatidylinositol 3-kinase signaling pathway in human colon cancer cells. Int J Oncol. 2012 Mar;40(3):816-24.

38 Cristofoletti C, Bresin A, Picozza M, Picchio MC, Monzo F, Helmer Citterich M, et al. Blood and skin-derived Sezary cells: differences in proliferation-index, activation of $\mathrm{PI} 3 \mathrm{~K} / \mathrm{AKT} / \mathrm{mTORC} 1$ pathway and its prognostic relevance. Leukemia. 2019 May;33(5): 1231-42.

39 Herrero-Sánchez MC, Rodríguez-Serrano C, Almeida J, San Segundo L, Inogés S, SantosBriz Á, et al. Targeting of PI3K/AKT/mTOR pathway to inhibit $\mathrm{T}$ cell activation and prevent graft-versus-host disease development. J Hematol Oncol. 2016 Oct;9(1):113.

40 Zarebska Z. Cell membrane, a target for PUVA therapy. J Photochem Photobiol B. 1994 May;23(2-3):101-9.

41 Van Aelst B, Devloo R, Zachée P, t'Kindt R, Sandra K, Vandekerckhove P, et al. Psoralen and Ultraviolet A Light Treatment Directly Affects Phosphatidylinositol 3-Kinase Signal Transduction by Altering Plasma Membrane Packing. J Biol Chem. 2016 Nov;291(47): 24364-76.
42 Cho A, Jantschitsch C, Knobler R. Extracorporeal Photopheresis-An Overview. Front Med (Lausanne). 2018 Aug;5:236.

43 Suchin KR, Cassin M, Washko R, Nahass G, Berkson M, Stouch B, et al. Extracorporeal photochemotherapy does not suppress $\mathrm{T}$ - or B-cell responses to novel or recall antigens. J Am Acad Dermatol. 1999 Dec;41(6):980-6.

44 Kühtreiber WM, Hayashi T, Dale EA, Faustman DL. Central role of defective apoptosis in autoimmunity. J Mol Endocrinol. 2003 Dec; 31(3):373-99.

45 Casciola-Rosen LA, Anhalt G, Rosen A. Autoantigens targeted in systemic lupus erythematosus are clustered in two populations of surface structures on apoptotic keratinocytes. J Exp Med. 1994 Apr;179(4):1317-30.

46 Schmitt IM, Chimenti S, Gasparro FP. Psoralen-protein photochemistry - a forgotten field. J Photochem Photobiol B. 1995 Feb; 27(2):101-7.

47 Schmitt IM, Moor AC, Patrignelli R, Chimenti S, Beijersbergen van Henegouwen GM, Edelson RL, et al. Increased surface expression of class I MHC molecules on immunogenic cells derived from the xenogenization of P815 mastocytoma cells with 8-methoxypsoralen and long-wavelength ultraviolet radiation. Tissue Antigens. 1995 Jul;46(1):45-9.

48 Yoo EK, Rook AH, Elenitsas R, Gasparro FP, Vowels BR. Apoptosis induction of ultraviolet light $\mathrm{A}$ and photochemotherapy in cutaneous T-cell Lymphoma: relevance to mechanism of therapeutic action. J Invest Dermatol. 1996 Aug;107(2):235-42.

49 Durazzo TS, Tigelaar RE, Filler R, Hayday A, Girardi M, Edelson RL. Induction of monocyte-to-dendritic cell maturation by extracorporeal photochemotherapy: initiation via direct platelet signaling. Transfus Apheresis Sci. 2014 Jun;50(3):370-8.

50 Li G, Kim YJ, Mantel C, Broxmeyer HE. Pselectin enhances generation ofCD14+CD16+ dendritic-like cells and inhibits macrophage maturation from human peripheral blood monocytes. J Immunol. 2003 Jul;171(2):66977.

51 Ventura A, Vassall A, Robinson E, Filler R, Hanlon D, Meeth K, et al. Extracorporeal Photochemotherapy Drives Monocyte-toDendritic Cell Maturation to Induce Anticancer Immunity. Cancer Res. 2018 Jul;78(14) 4045-58.

52 Anguille S, Smits EL, Lion E, van Tendeloo VF, Berneman ZN. Clinical use of dendritic cells for cancer therapy. Lancet Oncol. 2014 Jun;15(7):e257-67.

53 Gilboa E. DC-based cancer vaccines. J Clin Invest. 2007 May;117(5):1195-203.

54 Perez CR, De Palma M. Engineering dendritic cell vaccines to improve cancer immunotherapy. Nat Commun. 2019 Nov;10(1):5408.

55 Berger CL, Hanlon D, Kanada D, Girardi M, Edelson RL. Transimmunization, a novel approach for tumor immunotherapy. Transfus Apheresis Sci. 2002 Jun;26(3):205-16.

56 Berger C, Hoffmann K, Vasquez JG, Mane S, Lewis J, Filler R, et al. Rapid generation of maturationally synchronized human dendritic cells: contribution to the clinical efficacy of extracorporeal photochemotherapy. Blood. 2010 Dec;116(23):4838-47. 
57 Kibbi N, Sobolev O, Girardi M, Edelson RL. Induction of anti-tumor CD8 T cell responses by experimental ECP-induced human dendritic antigen presenting cells. Transfus Apheresis Sci. 2016 Aug;55(1):146-52.

58 Tatsuno K, Yamazaki T, Hanlon D, Han P, Robinson E, Sobolev O, et al. Extracorporeal photochemotherapy induces bona fide immunogenic cell death. Cell Death Dis. 2019 Aug;10(8):578.

59 Zhou J, Wang G, Chen Y, Wang H, Hua Y, Cai Z. Immunogenic cell death in cancer therapy: present and emerging inducers. J Cell Mol Med. 2019 Aug;23(8):4854-65.

60 Coppard C, Hannani D, Humbert M, Gauthier V, Plumas J, Merlin E, et al. In vitro PUVA treatment triggers calreticulin exposition and HMGB1 release by dying $\mathrm{T}$ lymphocytes in GVHD: new insights in extracorporeal photopheresis. J Clin Apher. 2019 Aug;34(4):450-60.

61 O'Sullivan BJ, Thomas HE, Pai S, Santamaria P, Iwakura Y, Steptoe RJ, et al. IL-1 beta breaks tolerance through expansion of CD25+ effector T cells. J Immunol. 2006 Jun; 176(12):7278-87

62 Baxevanis CN, Dedoussis GV, Gritzapis AD Stathopoulos GP, Papamichail M. Interleukin 1 beta synergises with interleukin 2 in the outgrowth of autologous tumour-reactive CD8+ effectors. Br J Cancer. 1994 Oct;70(4):625-30.

63 Guma M, Ronacher L, Liu-Bryan R, Takai S, Karin M, Corr M. Caspase 1-independent activation of interleukin-1beta in neutrophilpredominant inflammation. Arthritis Rheum. 2009 Dec;60(12):3642-50.

64 Yakut E, Jakobs C, Peric A, Michel G, Baal N, Bein G, et al. Extracorporeal photopheresis promotes IL-1 $\beta$ production. J Immunol. 2015 Mar;194(6):2569-77.

65 Shiue LH, Alousi AM, Wei C, Hosing CM, Duvic M, Ni X. Augmentation of blood dendritic cells by extracorporeal photopheresis in patients with leukemic cutaneous T-cell lymphoma and graft-versus-host disease. J Invest Dermatol. 2013 Aug;133(8):2098-100.

66 Vowels BR, Cassin M, Boufal MH, Walsh LJ, Rook AH. Extracorporeal photochemotherapy induces the production of tumor necrosis factor-alpha by monocytes: implications for the treatment of cutaneous T-cell lymphoma and systemic sclerosis. J Invest Dermatol. 1992 May;98(5):686-92.

67 Ayyildiz E, Arslan O, Topçuoğlu P, Arat M, Dalva K, Soydan EA, et al. The effect of extracorporeal photoimmunotherapy (ECP) on serum TNF-a level in chronic graft versus host disease (GvHD). Transfus Apheresis Sci. 2007 Feb;36(1):79-85.

68 Tokura Y, Seo N, Yagi H, Takigawa M. Photoactivational cytokine-modulatory action of 8-methoxypsoralen plus ultraviolet A in lymphocytes, monocytes, and cutaneous $\mathrm{T}$ cell lymphoma cells. Ann N Y Acad Sci. 2001 Sep; 941(1):185-93.

69 Di Renzo M, Rubegni P, De Aloe G, Paulesu L, Pasqui AL, Andreassi L, et al. Extracorporeal photochemotherapy restores Th1/Th2 imbalance in patients with early stage cutaneous T-cell lymphoma. Immunology. 1997 Sep;92(1):99-103

70 Guenova E, Watanabe R, Teague JE, Desimone JA, Jiang Y, Dowlatshahi M, et al. TH2 cytokines from malignant cells suppress TH1 responses and enforce a global $\mathrm{TH} 2$ bias in leukemic cutaneous T-cell lymphoma. Clin Cancer Res. 2013 Jul;19(14):3755-63.

71 Di Renzo M, Rubegni P, Pasqui AL, Pompella G, De Aloe G, Sbano P, et al. Extracorporeal photopheresis affects interleukin (IL)-10 and IL-12 production by monocytes in patients with chronic graft-versus-host disease. $\mathrm{Br} \mathrm{J}$ Dermatol. 2005 Jul;153(1):59-65.

72 Di Renzo M, Sbano P, De Aloe G, Pasqui AL, Rubegni P, Ghezzi A, et al. Extracorporeal photopheresis affects co-stimulatory molecule expression and interleukin-10 production by dendritic cells in graft-versus-host disease patients. Clin Exp Immunol. 2008 Mar; 151(3):407-13.

73 Pilon C, Stehlé T, Beldi-Ferchiou A, Matignon $\mathrm{M}$, Thiolat $\mathrm{A}$, Burlion $\mathrm{A}$, et al. Human Apoptotic Cells, Generated by Extracorporeal Photopheresis, Modulate Allogeneic Immune Response. Front Immunol. 2019 Dec;10:2908.

74 Alcindor T, Gorgun G, Miller KB, Roberts TF, Sprague K, Schenkein DP, et al. Immunomodulatory effects of extracorporeal photochemotherapy in patients with extensive chronic graft-versus-host disease. Blood. 2001 Sep;98(5):1622-5.

75 Holtick U, Marshall SR, Wang XN, Hilkens CM, Dickinson AM. Impact of psoralen/ UVA-treatment on survival, activation, and immunostimulatory capacity of monocytederived dendritic cells. Transplantation. 2008 Mar;85(5):757-66.

76 Klosner G, Trautinger F, Knobler R, Neuner $\mathrm{P}$. Treatment of peripheral blood mononuclear cells with 8-methoxypsoralen plus ultraviolet $\mathrm{A}$ radiation induces a shift in cytokine expression from a Th1 to a Th2 response. J Invest Dermatol. 2001 Mar;116(3):459-62

77 Girkontaite I, Urbonaviciute V, Maseda D, Neubert K, Herrmann M, Voll RE. Apoptotic cells selectively suppress the Th1 cytokine interferon gamma in stimulated human peripheral blood mononuclear cells and shift the Th1/Th2 balance towards Th2. Autoimmunity. 2007 Jun;40(4):327-30.

78 Kim S, Elkon KB, Ma X. Transcriptional suppression of interleukin-12 gene expression following phagocytosis of apoptotic cells. Immunity. 2004 Nov;21(5):643-53.

79 Lamioni A, Parisi F, Isacchi G, Giorda E, Di Cesare S, Landolfo A, et al. The immunological effects of extracorporeal photopheresis unraveled: induction of tolerogenic dendritic cells in vitro and regulatory $\mathrm{T}$ cells in vivo. Transplantation. 2005 Apr;79(7):846-50.

80 Wiese F, Reinhardt-Heller K, Volz M, Gille C, Köstlin N, Billing $\mathrm{H}$, et al. Monocytes show immunoregulatory capacity on CD $4+\mathrm{T}$ cells in a human in-vitro model of extracorporeal photopheresis. Clin Exp Immunol. 2019 Mar; 195(3):369-80.

81 Cohen N, Mouly E, Hamdi H, Maillot MC, Pallardy M, Godot V, et al. GILZ expression in human dendritic cells redirects their maturation and prevents antigen-specific T lymphocyte response. Blood. 2006 Mar; 107(5):2037-44.

82 Futterleib JS, Feng H, Tigelaar RE, Choi J, Edelson RL. Activation of GILZ gene by photoactivated 8-methoxypsoralen: potential role of immunoregulatory dendritic cells in extra- corporeal photochemotherapy. Transfus Apheresis Sci. 2014 Jun;50(3):379-87.

83 Maeda A, Schwarz A, Kernebeck K, Gross N, Aragane Y, Peritt D, et al. Intravenous infusion of syngeneic apoptotic cells by photopheresis induces antigen-specific regulatory $\mathrm{T}$ cells. J Immunol. 2005 May;174(10):5968-76.

84 Maeda A, Schwarz A, Bullinger A, Morita A, Peritt D, Schwarz T. Experimental extracorporeal photopheresis inhibits the sensitization and effector phases of contact hypersensitivity via two mechanisms: generation of IL-10 and induction of regulatory T cells. J Immunol. 2008 Nov; 181(9):5956-62.

85 Gatza E, Rogers CE, Clouthier SG, Lowler KP, Tawara I, Liu C, et al. Extracorporeal photopheresis reverses experimental graft-versushost disease through regulatory T cells. Blood. 2008 Aug;112(4):1515-21.

86 Bladon J, Taylor P. Extracorporeal photopheresis normalizes some lymphocyte subsets (including T regulatory cells) in chronic graftversus-host-disease. Ther Apher Dial. 2008 Aug;12(4):311-8

87 Rubegni P, Sbano P, Cevenini G, Perari MG, Marotta G, Risulo M, et al. CD4+CD25+ lymphocyte subsets in chronic graft versus host disease patients undergoing extracorporeal photochemotherapy. Int J Immunopathol Pharmacol. 2007 Oct-Dec;20(4):801-7.

88 Biagi E, Di Biaso I, Leoni V, Gaipa G, Rossi $\mathrm{V}$, Bugarin C, et al. Extracorporeal photochemotherapy is accompanied by increasing levels of circulating CD4+CD25+GITR+Foxp3+CD62L+ functional regulatory $\mathrm{T}$-cells in patients with graft-versus-host disease. Transplantation. 2007 Jul;84(1):31-9.

89 Schmitt S, Johnson TS, Karakhanova S, Näher H, Mahnke K, Enk AH. Extracorporeal photophoresis augments function of CD4+CD25+FoxP3+ regulatory $\mathrm{T}$ cells by triggering adenosine production. Transplantation. 2009 Aug;88(3):411-6.

90 Deaglio S, Dwyer KM, Gao W, Friedman D, Usheva A, Erat A, et al. Adenosine generation catalyzed by CD39 and CD73 expressed on regulatory $\mathrm{T}$ cells mediates immune suppression. J Exp Med. 2007 Jun;204(6):1257-65.

91 Denney HA, Whittle RJ, Lai J, Jacques RM, Taylor PC, Regulatory T. Regulatory T Cells in Chronic Graft-Versus-Host Disease After Extracorporeal Photopheresis: Correlation With Skin and Global Organ Responses, and Ability to Taper Steroids. Transplantation. 2017 Jan;101(1):204-11.

92 Wei YX, Sun B, Xiao L, Shi BY. Infusion of Lymphocytes Treated With 8-Methoxypsoralen and Ultraviolet $A$ Light Induces CD19+IL-10+ Regulatory B Cells and Promotes Skin Allograft Survival. Transplant Proc. 2018 Dec;50(10):3906-10.

93 Whittle R, Taylor PC. Circulating B-cell activating factor level predicts clinical response of chronic graft-versus-host disease to extracorporeal photopheresis. Blood. 2011 Dec; 118(24):6446-9.

94 Hequet O, Nosbaum A, Guironnet-Paquet A, Blasco E, Nicolas-Virelizier E, Griffith TS, et al. CD8+ T cells mediate ultraviolet A-induced immunomodulation in a model of extracorporeal photochemotherapy. Eur J Immunol. 2020 May;50(5):725-35. 